\title{
Hydrological Model and GIS-Based Estimation of Hydropower and Solar Energy Potential in Patimban Area, Indonesia
}

\author{
Miga Magenika Julian ${ }^{1,2^{*}}$, Ruri Agung Wahyuono ${ }^{3}$, Eko Agus Prasetio ${ }^{4}$, and \\ Poerbandono Poerbandono ${ }^{1}$ \\ ${ }^{1}$ Hydrography Research Group, Institut Teknologi Bandung, Jl. Ganesha 10, \\ Bandung 40132, Indonesia \\ ${ }^{2}$ Geographic Information Science, Friedrich-Schiller-Universität Jena, Löbdergraben 32, \\ 07743 Jena, Germany \\ ${ }^{3}$ Department of Engineering Physics, Institut Teknologi Sepuluh November, Keputih, Sukolilo, \\ Surabaya 60111, Indonesia \\ ${ }^{4}$ School of Business and Management, Institut Teknologi Bandung, Jl. Ganesha 10, \\ Bandung 40132, Indonesia
}

\begin{abstract}
This study aims at mapping and evaluating the hydropower and solar energy potential in the Patimban area, Subang district, West Java Indonesia, within the vicinity of Patimban Deep-Sea Port construction. The hydrological model, the geographic information system (GIS), and climatology data were exploited to assist the estimation of the site-specific hydropower and solar energy potential. The results at hand reveal that the Patimban area exhibit a promising potential to develop both pico and micro hydropower plants for domestic energy supply in the urban area close to the seaport. Meanwhile, the solar energy potentials in merely 12 ha area determined from the sunshine durations in the Patimban area enable to adequately supply the approximated energy demand of the Patimban DeepSea Port operation. The financing scheme for funding this renewable energy power plant is briefly discussed and proposed as an alternative to the limited budget for the Patimban Deep-Sea Port construction. Overall, the hydrological model and GIS demonstrate their applicability in assessing the potential of environmental sources of renewable energy.
\end{abstract}

Keywords: Deep-Sea Port, financing scheme, mapping, renewable energy, spatial modeling.

\section{Introduction}

Patimban area is currently under rapid construction for a deep-sea port and expected to be operational by the end of 2019. Notably, the Patimban Deep-Sea Port has been designed to have half of the capacity of Tanjung Priok Port, the largest port in Indonesia. In addition, the operation of Patimban Port will be synergized with the Tanjung Priok Port or other ports to meet the demand of terminal capacity [1]. Considering the considerably large terminal capacity, the Patimban Port requires huge energy, particularly electricity, for operational activities. As the annual operation of the Tanjung Priok Port consumes energy

\footnotetext{
* Corresponding author: miga.m.julian@gmail.com
} 
up to 57 Mio kWh supplied by the private energy supplier, the Patimban Port will,

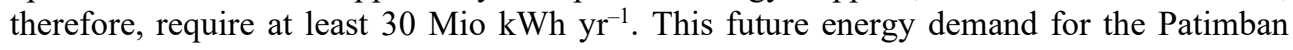
Port will mostly be supplied by the conventional electricity grid provided by the national electricity company (PT. PLN). However, the exploitation of renewable energy potential for partially supplying electricity needs will attract promising private investments in Patimban area and will support the national energy mix target, i.e., increasing greener and cleaner energy utilization.

The study at hand intends to provide insight concerning renewable energy potential in the Patimban area, which is limited to the discussion of hydropower and solar energy potential. The spatial distribution of hydropower and solar energy potential is investigated within the region of interest in the vicinity of the Patimban Deep-Sea Port, Subang district, West Java, Indonesia. Following the earlier report, a hydrological model, a geographic information system (GIS) and climatology data can be utilized to assist the estimation of the site-specific hydropower and solar energy potential: The integration of spatial datasets, climatology data, and rate of flows based hydrological modelling in the GIS project improves data management for exploratory analysis of renewable energy potential [2]. This study further presents the optimized configuration of the available installation of solar and hydropower and the estimation of the maximum energy mix at the Patimban Port. In the context of the financing scheme for renewable energy installation projects, a proposed alternative of financing scheme will be briefly discussed since the government of Indonesian, in particular the Ministry of National Development Planning (BAPPENAS), mentioned that the government could afford to fulfill only $41.3 \%$ of total infrastructure cost, which is highly unlikely spent for renewable energy projects.

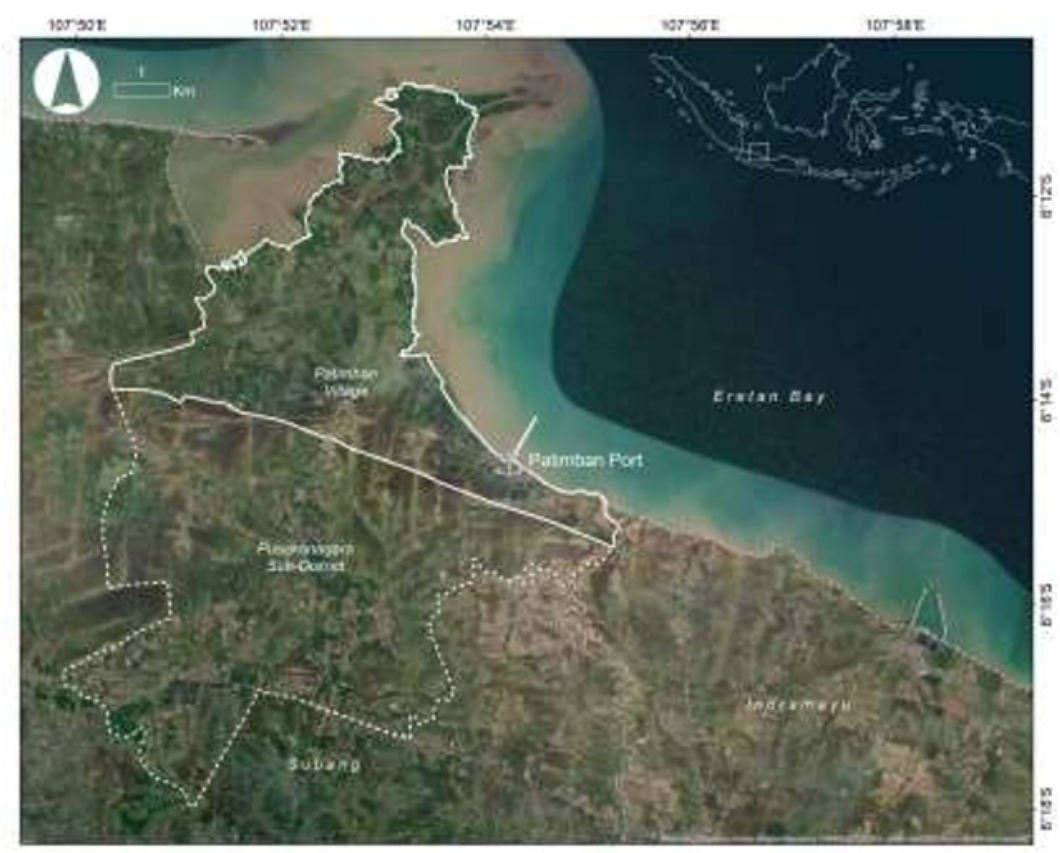

Fig. 1. The study area: The Patimban port (anchor symbol), the Patimban village boundary (white line), the Pusakanagara Sub-District boundary (white-dashed line), and the district boundary (greydashed line). 


\section{Method}

\subsection{Characteristics of the Patimban area}

The study area is situated in the Patimban area, West Java, Java Island, Indonesia (Figure 1). Patimban is a village in the Pusakanagara Sub-District, Subang District. The total area of Patimban is 2311.71 ha or approximately $39 \%$ of the total area of the Pusakanagara Sub-District. The elevation is found ranging from $0 \mathrm{~m}$ to $11 \mathrm{~m}$, with an average of $1.8 \mathrm{~m}$. This area hosts the Cipunagara river which flows through and has its outlets in the northern part of Patimban area. The Patimban Deep-Sea Port is positioned in the coordinate of $-6^{\circ} 14^{\prime} 36.66^{\prime \prime}$ latitude and $107^{\circ} 54^{\prime} 15.45^{\prime \prime}$ longitude. In this study, the assessment of sources of renewable energy assumes that the entire administrative area of the Pusakanagara Sub-District could be explored and exploited.

\subsection{Mapping of the hydropower and solar energy potential with hydrological modelling and GIS}

Mapping of the hydropower and solar energy potential was carried out following the procedure schematically shown in Figure 2. The geographic information system (GIS) and the hydrological model were implemented to estimate the potential sources of hydropower and solar energy. Implementation of the hydrological model enables the simulation of the river flow rate, which is the forcing parameter for hydropower estimation. GIS provided an assistance in the spatial modeling for extracting the hydrologic information, such as drainage networks, watershed boundaries, and slope-head parameter $(h)$ from a digital elevation model (DEM). Furthermore, GIS was used to implement the mathematical model of the spatial data using the model builder toolbox.

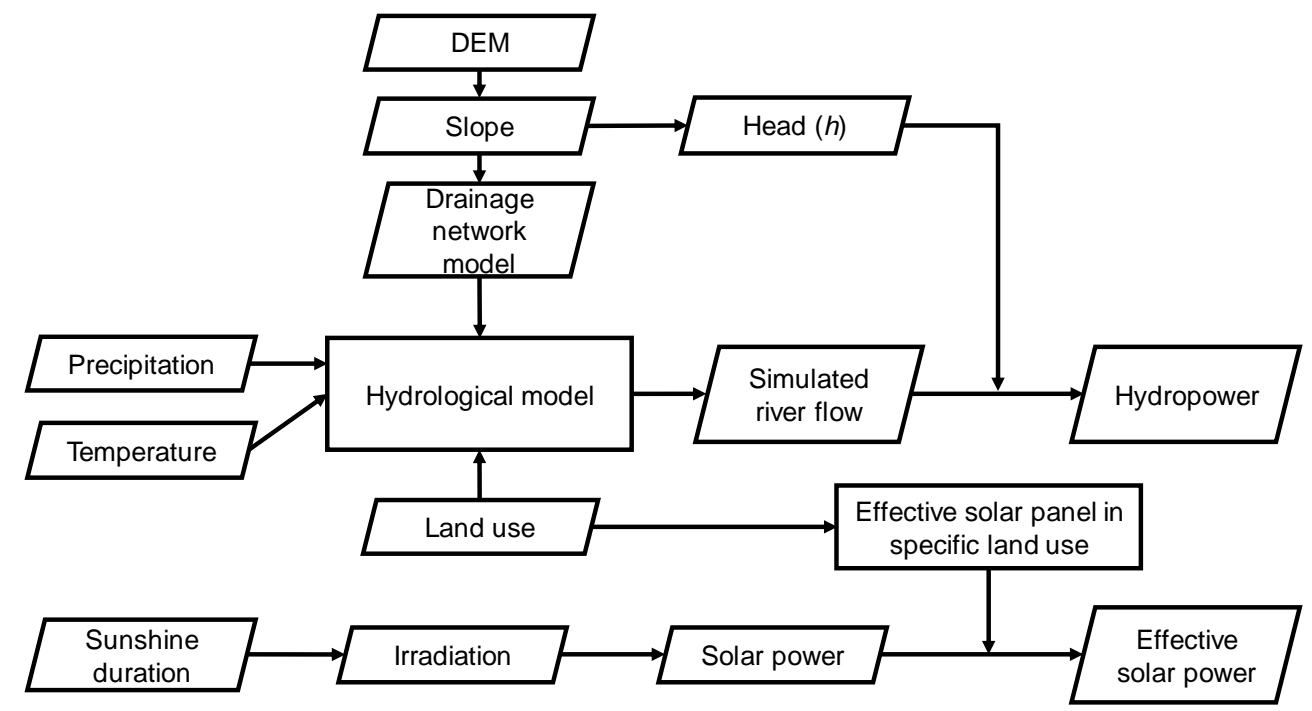

Fig. 2. Flow diagram of data collection and processing for hydropower and solar energy estimation.

\subsubsection{Estimating of hydropower output}

The hydropower is correlated to the hydrological cycle, which presents the water movement on Earth [2]. It begins from the fall of precipitation drained into the river basin that controls the amount of available forcing water for producing hydropower. The hydropower is 
categorized by the net power output from the system. Characteristically, the hydropower can be classified into pico-hydro, micro-hydro, mini-hydro, small, medium, and large hydropower. In order to assess the net power output of the employment hydropower potential, the power output available from falling water $\left(E_{\text {hydro }}\right)$ can be estimated by Equation (1):

$$
E_{\text {hydro }}=\eta_{G} \cdot \eta_{T} \cdot \rho \cdot g \cdot h \cdot Q
$$

Where $\eta_{G}$ is the efficiency of the generator, $\eta_{T}$ is the efficiency of the hydro-turbine, $\rho$ is the density of water $\left(\mathrm{kg} \mathrm{m}^{-3}\right), \mathrm{g}$ is the acceleration due to gravity $\left(9.8 \mathrm{~m} \mathrm{~s}^{-2}\right)$, and $h$ is the falling height, head $(\mathrm{m}), Q$ is the volumetric flow rate $\left(\mathrm{m}^{3} \mathrm{~s}^{-1}\right)$. The $\eta_{G}$ ranges from $0.85-$ 0.93 , while the $\eta_{T}$ ranges from 0.75 to 0.95 depending on the type of turbine used in the system. Spatially, the hydropower output depends on the product $h$ and $Q$. This in turn consequently means that a high dam with a large $h$ and a small $Q$ could produce a hydropower output as high as a run-of-river installation with a small $h$ and large $Q$ [3].

The parameter $Q$ was simulated based on the hydrological modeling. In this study, a raster-based spatially distributed hydrological model named STREAM hydrological model [4] was used. STREAM applied the Thornthwaite-Mather's water balance approach to calculate flow discharges along with drainage networks derived from a DEM. STREAM employed the Thornthwaite equations [5] for potential evapotranspiration and the Thornthwaite and Mather equations [6] for actual evapotranspiration. The main inputs to the model were the climatology data (maps of precipitation and temperature), a DEM, and the land use maps. The calibration parameters of the STREAM model were adapted from the literature $[7,8]$. The falling height as well as the slope-head parameter, $h$, was calculated based on the different elevation between one pixel and surrounding pixels on the DEM. The correlations between the hydropower output, the river flow, and the head parameter were evaluated using Pearson's correlation coefficient $(R)$.

\subsubsection{Estimating of solar energy output}

It is known that solar energy potential is determined from the solar irradiance and hence, the solar irradiation in this work was estimated from the sunshine duration following the literature [9-12]. The solar radiation $(R s)$ was calculated based on the reported model $[9,10]$ as Equation (2):

$$
R s=\left(a+b \cdot \frac{S}{S_{0}}\right) \cdot R a
$$

Where $S$ is the actual sunshine hour, $S_{0}$ is the maximum possible sunshine hour, $a$ and $b$ are the Angstrøm coefficients, and $R_{a}$ is the extra-terrestrial radiation. In this study, $a$ and $b$ are set to 0.25 and 0.75 , respectively. The $S_{0}$ was estimated as Equation (3):

$$
S_{0}=\frac{2}{15} \cdot \omega
$$

Where $\omega$ is the hour angle at sunset for the particular geographical latitude $(\varphi)$ and declination $(\delta)$. The $\omega$ and $\delta$ were determined from the following Equation (4) and Equation (5):

$$
\begin{gathered}
\omega=\cos ^{-1}(-1 \cdot \tan \varphi \cdot \tan \delta) \\
\delta=23.45 \cdot \sin \left[\frac{360}{365} \cdot(n+284)\right]
\end{gathered}
$$


Where $\mathrm{n}$ is the day number in a year: $\mathrm{n}=1$ for the 1 st of January and $\mathrm{n}=365$ for the 31 st of December. The extra-terrestrial radiation $(\mathrm{Ra})$ was calculated from the following formula [11] in Equation (6):

$$
\begin{aligned}
& R a=\frac{24}{\pi} \cdot I_{S C} \cdot\left(1+0.033 \cdot \cos \frac{360 n}{365}\right) \\
& \left(\cos \varphi \cdot \cos \varphi \cdot \sin \omega+\frac{\pi}{180} \cdot \omega \cdot \sin \varphi \cdot \sin \delta\right)
\end{aligned}
$$

where the $I_{S C}$ is the solar constant $\left(I_{S C}=1367 \mathrm{~W} \mathrm{~m}^{-2}\right)$.

The solar energy potential of specific area was represented by the daily energy output $\left(E_{P V}\right)$ of PV system simulated in grid-connected PV system using PVsyst V.5.14 [12]. In principle, the $E_{P V}$ was calculated using the peak hours Equation (7) as follows:

$$
E_{P V}=\frac{P_{\text {rated }} \times S_{\text {in }}}{\Phi_{A M 1.5 G}}
$$

where $P_{\text {rated }}$ is rated peak power of PV panel (Wp), $S_{\text {in }}$ is insolation $\left(\mathrm{kWh} \mathrm{m}^{-2} \mathrm{~d}^{-1}\right)$, and $\Phi_{A M 1.5 G}$ is radiative power flux at peak sun $\left(\mathrm{W} \mathrm{m}^{-2}\right)$. This equation implies that a $\mathrm{PV}$ panel receives a regular $S / \Phi_{A M 1.5 G}$ peak hours of sun per day (a square-wave function). However, this leads to an overestimation of the energy output from the PV array since the power conversion efficiency of PV declines at lower irradiation. Therefore, the radiative power flux was modeled as a Gaussian wave instead of a square wave. The solar energy equations were spatially calculated in the ESRI ArcGIS version 10 using model builder tool [12].

\section{Results and discussions}

The analysis based on the hydrological model and GIS unravels the spatial distribution of hydropower in the Patimban area (Figure 3). As much as (at least) 49 potential sites of hydropower plants have been identified, in which the hydropower potential ranges from $0.1 \mathrm{kWh}$ to $54.72 \mathrm{kWh}$ with an average value of $5.54 \mathrm{kWh}$. Among these ranges of net power output, the Patimban area is potentially able to develop and install the pico and micro hydropower plant, with a sharing area of $71 \%$ and $29 \%$, respectively. The higher potential of micro hydropower is noticeable in the tributary of the main river order, where it has a high river flow rate. These results obtained here are in line with the earlier report [13], which finds that the hydro energy potential in Indonesia is dominated by the pico to the mini hydropower plant. In addition, it is also suggested that the head parameter $(h)$ less than $30 \mathrm{~m}$ will be projected as a potential source for micro-hydropower plant [14]. Here, the available modeled head over the Patimban area varies between $0 \mathrm{~m}$ and $14.23 \mathrm{~m}$, with an average of $4.57 \mathrm{~m}$. Typically, the area with a high head is very few to find in the northern part of Java.

To further evaluate the hydrological model for hydropower estimation, a simple linear correlation between the hydropower output and either the simulated river flow or the head parameter is determined and shown in Figure 4. Interestingly, it is found that the linear correlation of the river flow $(R=0.73)$ is stronger than the head correlation $(R=0.17)$. In the Patimban area, the hydropower output is more sensitive to the river flow variability than the head variability. This result can be understood by cause of the less variability of the elevation, which generates the slope-head parameter in the downstream area.

Considering that the entire micro-hydropower plants that could be established, a net energy generation of $89.46 \mathrm{MWh} \mathrm{yr}^{-1}$ could be achieved. Meanwhile, the pico-hydropower plants enable 9.58 MWh net energy generation. In summary, the hydropower output in the Patimban area is listed in Table 1. This projected energy output from hydropower potential 
in the Patimban area might contribute to support $0.33 \%$ of the operational energy needed at the Patimban Port. This result indicates that hydropower potential alone is not sufficient to support the operational energy needed at Patimban port. Nonetheless, it is worth noting that the hydropower potential remains beneficial for the complimentary domestic energy supply for the urban area close to the seaport.

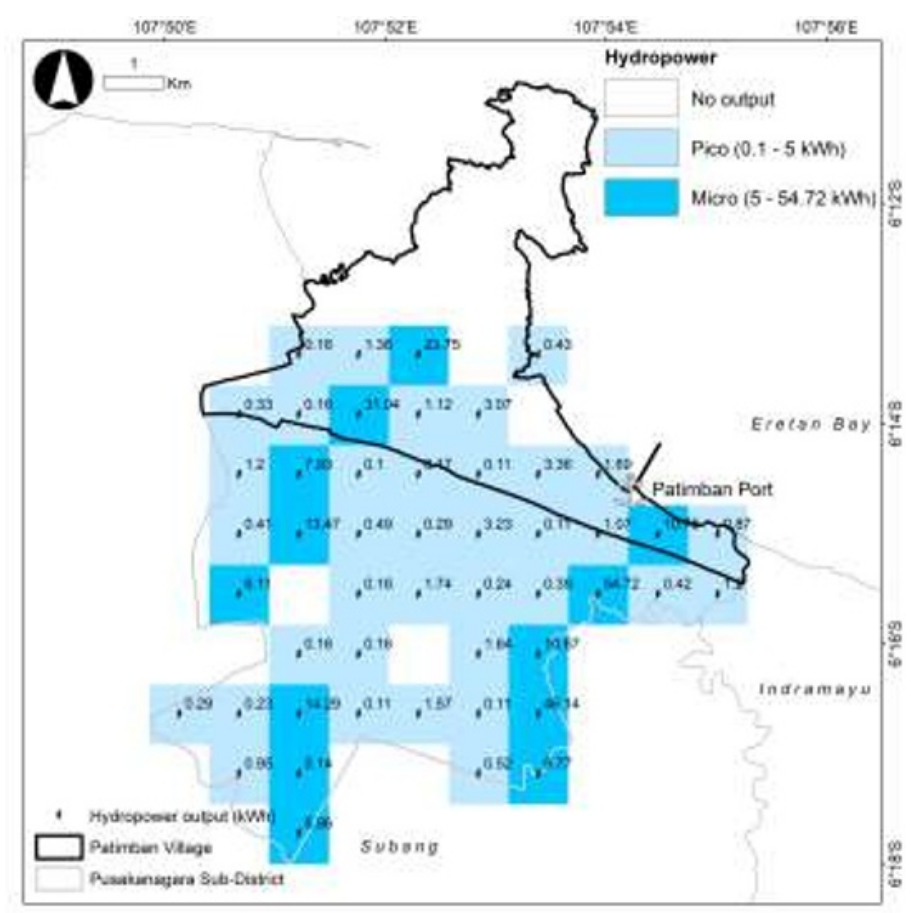

Fig. 3. The spatial mapping of estimated hydropower plant over the Patimban area, including picoand micro-hydropower plants.

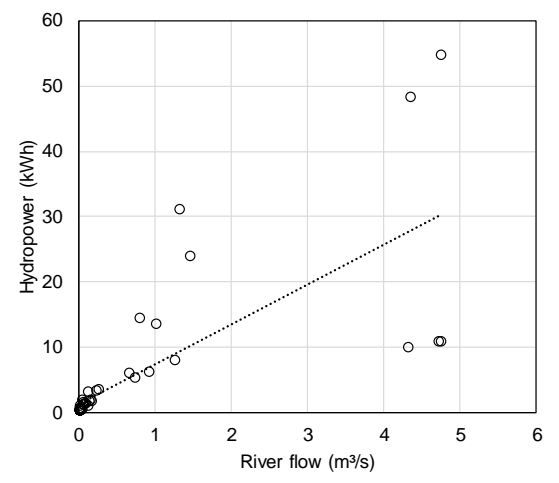

(a) Hydropower and flow discharge

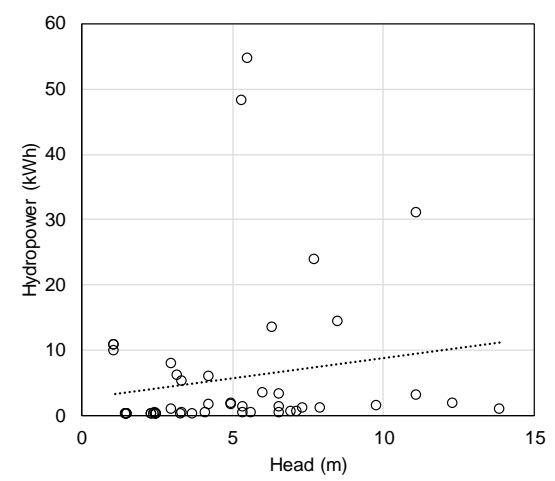

(b) Hydropower and head parameter

Fig. 4. Scatter plot of estimated hydropower and estimated flow discharge (a), and estimated hydropower and slope head parameter (b). 
Table 1. Estimated of hydropower plant type and total hydropower output.

\begin{tabular}{cccc}
\hline Power plant type & Number of sites & Total power (MWh) & \% of total power \\
\hline Pico-hydro & $35(71 \%)$ & 9.58 & 9.68 \\
Micro-hydro & $14(29 \%)$ & 89.46 & 90.32 \\
\hline
\end{tabular}

Having evaluated the hydropower potential, solar energy potential is discussed by unraveling the spatial variability of solar irradiance in the Patimban area. The resultant estimated spatial variability in solar irradiance is displayed in Figure 5: The irradiance varies between $3.49 \mathrm{kWh}$ and $3.63 \mathrm{kWh}$, with an average of $3.59 \mathrm{kWh}$. Higher irradiances are found in the northern part of Patimban following the lower latitude, i.e., closer to the equator line. In addition, the specific land-use classes (Table 2) are applied to estimate the effective area used for solar PV power plants, which include rainfed cropland, herbaceous cover, irrigated cropland, mosaic natural vegetation, urban area, and water bodies.

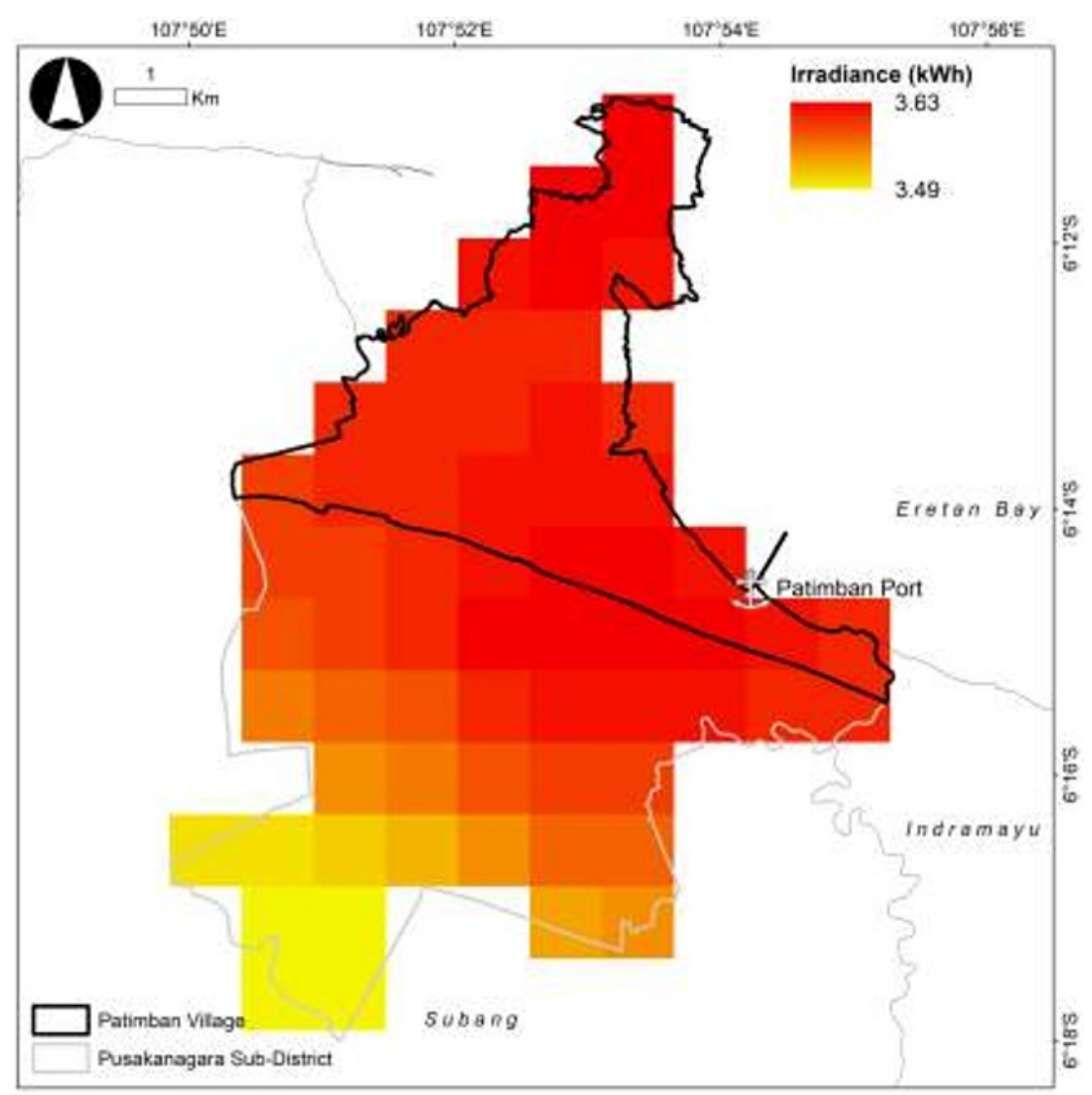

Fig. 5. The spatial mapping of estimated irradiance over the Patimban area to calculate the solar energy output. 
Table 2. Total effective solar energy output based on land use classification.

\begin{tabular}{cccc}
\hline Land-use type & $\begin{array}{c}\text { Area } \\
\text { (ha) }\end{array}$ & $\begin{array}{c}\text { Effective area for } \\
\text { solar panel }\end{array}$ & $\begin{array}{c}\text { Total solar energy } \\
(\text { Mio kWh })\end{array}$ \\
\hline Cropland, rainfed & 2771 & $50 \%$ & 3323.18 \\
Herbaceous cover & 469 & $50 \%$ & 562.46 \\
$\begin{array}{c}\text { Cropland, irrigated } \\
\text { Mosaic natural vegetation }\end{array}$ & 521 & $30 \%$ & 374.89 \\
(tree, shrub, herbaceous cover) $(<50 \%)$ & 52 & $50 \%$ & 62.36 \\
Mosaic natural vegetation & 35 & $50 \%$ & 41.97 \\
(tree, shrub, herbaceous cover) $(>50 \%)$ & & $10 \%$ & 206.27 \\
Tree cover with flooded saline water & 860 & $10 \%$ & 81.31 \\
Urban areas & 339 & $0 \%$ & 0 \\
Water bodies & 851 & & \\
\hline
\end{tabular}

Taking into account the possible effective area for solar PV power plant installation for each land-use type yields a maximum solar energy output of 4652.45 Mio kWh per year. This total (theoretical) solar energy output is found 150 times higher than the approximated total energy demand of the Patimban Deep-Sea Port. With this abundant solar energy potential in the Patimban area, only 12.5 ha effective area is required to build the solar PV power plant which meets the energy demand for the Patimban Port. This solar PV power plant could be realized by building either a large area solar farm or PV microgrid. Nonetheless, it should be noted that this on-paper calculation, of course, has not counted the social acceptance on this proposed power plant installation as well as the possibility for funding these renewable energy projects. Furthermore, although the maximum solar energy production in this area can cover the whole energy need for annual operation of Patimban port, pico and micro-hydro systems can also be seen as the supporting energy generation since, in many areas, the water flow is found to be the highest in the wet season whilst the solar energy is at its minimum potential.

As motivated in the introduction, the alternative financing scheme for the renewable energy-based power plant will also be discussed. The development of hydropower and solar energy potential sources for the Patimban Port could be categorized in the infrastructure project. According to the Ministry of Finance, the Republic of Indonesia projects related to human capital development, infrastructure, and poverty eradication would have priorities from the government to be included in the Public-Private Partnership (PPP) program as a financing alternative. From the Presidential Regulation (PR), both PR No. 67/2005 and PR No. 38/2015, it is well defined that the PPP in Indonesia is only conducted to build infrastructure and as an available financing alternative for the infrastructure of renewable energy projects [15].

The PPP scheme includes three stages, i.e., (i) planning, (ii) preparation, and (iii) transaction. In the planning stage, two activities are carried out, including (i) project identification and (ii) preliminary study. The PPP project can be identified in three ways: (i) Proposed by Minister/Head of Institution/Head of Regional Government/Director of Stateowned Enterprise/Director of Regional-owned Enterprise, named Government Contracting Agency (GCA); (ii) Proposed by BAPPENAS based on the National Development Priority Program; and (iii) Proposed to GCA by business entity itself (unsolicited projects). The preliminary study stage is conducted by GCA which consists of needs analysis, compliance criteria, value for money analysis, analysis of potential revenue, and the project funding scheme, as well as recommendation and follow-up plan [15]. 
The PPP preparation stage comprises of a pre-feasibility study that consists of the outline business case, where the economic and commercial study, as well as the environmental and social study, are performed, and the final business case, in which the GCA needs to perform public consultation and market sounding. Public consultation is undertaken to review the PPP project's compliance with the social and environmental standards, as well as to obtain inputs of public needs related to the project. Market sounding is required to obtain inputs from the PPP market (business entities/agencies/institutions, etc.). Finally, the transaction stage consists of (i) pre-qualification, (ii) request for proposal, (iii) bidding award, (iv) agreement signing, and (v) financial close [15].

In case that this renewable energy project would be proposed by the (local) government, it will fall under the solicited project category. The project eligibility criteria for an under preparation solicited project will include (i) compliance with National/Regional Mid-term Development Plan and Strategic Plan of Infrastructure Sector, (ii) suitability of project location with the spatial plan, (iii) relating the inter-sector of infrastructure and inter-region, and (iv) the ownership of preliminary study documents [15]. Alternatively, this project could also be proposed by the business entity and falls into the unsolicited project category. The eligibility criteria will include (i) technical integration with the sector masterplan, (ii) economic and financial viability, and (iii) financial capability of the business entity that proposes the initiative [15].

\section{Conclusion}

This research has shown that the hydrological model and GIS can be implemented to spatially identify and assess the potential sources of hydropower and solar energy. In terms of hydropower estimation, pico- and micro-hydropower plants can be developed over the Patimban area. Meanwhile, the abundant sunshine hour in the Patimban area is potentially converted into solar energy as high as 150 times of the approximated energy demand of the Patimban Deep-Sea Port. This spatial approach is proven to be the appropriate tool to assess the environmental potential for renewable energy sources. Planners, decision-makers, and regulatory bodies, as well as other relevant stakeholders, might benefit much from this approach, particularly in advising the preparation of optimized selections of energy production area.

\section{References}

1. J. Malisan, International Journal of Innovations in Engineering and Technology (IJIET), 8,2:303-310(2017). http://ijiet.com/wp-content/uploads/2017/05/44.pdf

2. L. Matejicek. Assessment of energy sources using GIS. Berlin: Springer (2017). https://www.springer.com/de/book/9783319526935

3. B.C. Kusre, D.C. Baruah, P.K. Bordoloi, S.C. Patra, Applied Energy, 87,1:298309(2010). https://www.sciencedirect.com/science/article/pii/S0306261909003109

4. J.C.J.H. Aerts, M. Kriek, M. Schepel, Physics and Chemistry of the Earth Part B: Hydrology, Oceans and Atmosphere, 24,6:591-595(1999). https://www.sciencedirect.com/science/article/pii/S1464190999000490

5. M. Valipour, M.A.G. Sefidkouhi, M. Raeini, Agricultural Water Management 180:50-60(2017). https://www.sciencedirect.com/science/article/abs/pii/S0378377416303195

6. K. Gudulas, K. Voudouris, G. Soulios, G. Dimopoulos, Desalination and Water Treatment, 51,13-15:2945-2954(2013). https://www.tandfonline.com/doi/abs/10.1080/19443994.2012.748443 
7. R. Poerbandono, P.J. Ward, M.M. Julian, ITB Journal on Engineering Science 41,1:50-64(2009).

http://journals.itb.ac.id/index.php/jets/article/view/116

8. M.M. Julian, F. Nishio, Poerbandono, P.J. Ward, International Journal of Technology 2,1:37-46(2011). http://ijtech.eng.ui.ac.id/article/view/1017

9. A.M. Muzathik, W.B.W. Nik, M.Z. Ibrahim, K.B. Samo, K. Sopian, M.A. Alghoul, International Journal of Mechanical and Materials Engineering, 6,1:75-80(2011).

https://ukm.pure.elsevier.com/en/publications/daily-global-solar-radiation-estimatebased-on-sunshine-hours

10. H. Li, W. Ma, Y. Lian, X. Wang, L. Zhao, Renewable Energy, 36,11:31413145(2011).

https://www.sciencedirect.com/science/article/abs/pii/S0960148111001339

11. S. Zekai. Solar energy fundamentals and modeling techniques: atmosphere, environment, climate change and renewable energy, first ed. Springer, London (2008). https://www.springer.com/de/book/9781848001336

12. I. Ismail, G.K. Putri, R.H. Jannah, R. Hantoro, G. Nugroho, R.A. Wahyuono, et al., AIP Conf. Proc. 2088,1:030017(2019).

https://aip.scitation.org/doi/abs/10.1063/1.5095322

13. R.A. Wahyuono, M.M. Julian, MATEC Web of Conferences 164:01040-1-0104011(2018).

https://www.matecconferences.org/articles/matecconf/abs/2018/23/matecconf_icesti2018_01040/matecc onf_icesti2018_01040.html

14. M. Majumder. Minimization of climatic vulnerabilities on mini-hydro power plants: Fuzzy AHP, fuzzy ANP techniques and neuro-genetic model approach. Switzerland: Springer (2016). https://www.springer.com/de/book/9789812873132

15. G. Widjaja, International Journal of Economic Research 14:235-245(2017). https://serialsjournals.com/abstract/50756_18.pdf 